University of Nebraska - Lincoln

DigitalCommons@University of Nebraska - Lincoln

Publications from USDA-ARS / UNL Faculty

U.S. Department of Agriculture: Agricultural

Research Service, Lincoln, Nebraska

July 2008

\title{
Heterosis in Switchgrass: Spaced Plants
}

Juan M. Martinez-Reyna

Univ. Autónoma Agraria Antonio Narro, Buenavista, Saltillo, Coahuila, Mexico

Kenneth P. Vogel

University of Nebraska-Lincoln, kvogel1@unl.edu

Follow this and additional works at: https://digitalcommons.unl.edu/usdaarsfacpub

Part of the Agricultural Science Commons

Martinez-Reyna, Juan M. and Vogel, Kenneth P., "Heterosis in Switchgrass: Spaced Plants" (2008).

Publications from USDA-ARS / UNL Faculty. 213.

https://digitalcommons.unl.edu/usdaarsfacpub/213

This Article is brought to you for free and open access by the U.S. Department of Agriculture: Agricultural Research Service, Lincoln, Nebraska at DigitalCommons@University of Nebraska - Lincoln. It has been accepted for inclusion in Publications from USDA-ARS / UNL Faculty by an authorized administrator of DigitalCommons@University of Nebraska - Lincoln. 


\title{
Heterosis in Switchgrass: Spaced Plants
}

\author{
Juan M. Martinez-Reyna and Kenneth P. Vogel`
}

\begin{abstract}
Population and specific hybrids were made between populations and genotypes of switchgrass, Panicum virgatum L., and their progeny were evaluated for heterosis in space-transplanted field trials in eastern Nebraska for a 3-yr period. 'Kanlow' (lowland tetraploid) $\times$ 'Summer' (upland tetraploid) hybrids exhibit midparent heterosis for second- and third-year biomass yields for both population and individual plant hybrids. These data and previously reported molecular marker data indicate that lowland-tetraploid and upland-tetraploid switchgrasses represent different heterotic groups that can potentially be used to produce $F_{1}$ hybrid cultivars. Hybrids produced from cultivars and experimental strains developed from upland-octaploid germplasm originating from spatially separated western and eastern regions of the original tallgrass or an adjacent forested ecoregion did not exhibit heterosis for any trait evaluated. These results suggest that these upland populations evaluated were from the same or closely related large germplasm pools or heterotic groups. A method for developing $F_{1}$ switchgrass hybrid cultivars utilizing the gametophytic self-incompatibility mechanism of the species is described.
\end{abstract}

J.M. Martínez-Reyna, Univ. Autónoma Agraria Antonio Narro, Buenavista, Saltillo, Coahuila, Mexico; K.P. Vogel, USDA-ARS, 314 Biochemistry Hall, Univ. of Nebraska, P.O. Box 8307377, Lincoln, NE 68583-0737. The reported research is from a dissertation submitted by the senior author in partial fulfillment of the requirements for a Ph.D. degree at the University of Nebraska. The research was funded in part by the USDOE's Bioenergy Feedstock Development Program at Oak Ridge National Laboratory, USDA-ARS, and the University of Nebraska. Received 21 Dec. 2007. ${ }^{\star}$ Corresponding author (Ken. Vogel@ars.usda.gov).

Abbreviations: OBP, original base population; RAPD, random amplified polymorphic DNA; RFLP, restriction fragment length polymorphism.

Switchgrass (Panicum virgatum L.), is a $\mathrm{C}_{4}$ perennial grass native to North America that is being developed as a biomass energy crop in the United States for use on marginal cropland (McLaughlin and Kszos, 2005). Switchgrass has been used since the early 1940s for conservation purposes and for warm-season pastures in the Great Plains and Midwest states, with lesser use in other regions (Vogel, 2004). Regionally adapted cultivars have been developed for these uses. To improve its economic value as a biomass energy crop, switchgrass cultivars with significantly greater biomass yields need to be developed. All current switchgrass cultivars are improved populations or synthetic cultivars that were developed using breeding methods that utilize additive genetic variation (Vogel and Pedersen, 1993; Vogel, 2000). Grass breeders have not capitalized on nonadditive genetic variance to produce hybrid cultivars except where the hybrids can be propagated asexually or via apomictic mechanisms (Burton, 1989; Vogel, 2000; Vogel and Burson, 2004). Lack of information on

Published in Crop Sci. 48:1312-1320 (2008).

doi: 10.2135/cropsci2007.12.0695

(C) Crop Science Society of America

677 S. Segoe Rd., Madison, WI 53711 USA

All rights reserved. No part of this periodical may be reproduced or transmitted in any form or by any means, electronic or mechanical, including photocopying, recording, or any information storage and retrieval system, without permission in writing from the publisher. Permission for printing and for reprinting the material contained herein has been obtained by the publisher. 
the extent of heterosis and the identification of heterotic groups and effective mechanisms to emasculate or control pollination at the seed production field scale has delayed the effective use of hybrid cultivars for most perennial grass forage and biomass species, including switchgrass.

Heterosis or hybrid vigor is defined as the positive difference between the hybrid and the mean of the two parents (Lamkey and Edwards, 1999) for specific traits. This definition is referred to as midparent heterosis. High-parent heterosis is defined as the positive difference between the mean of the hybrid and the mean of the best parent. Heterosis can be expressed as a percentage, but when so expressed, it is difficult to conduct valid statistical tests for its existence. For statistical tests, heterosis is best expressed as a deviation from either the midparent (midparent heterosis) or best-parent mean (high-parent heterosis) (Lamkey and Edwards, 1999). Population or panmictic midparent heterosis occurs when two random-mated populations are intermated to form an $\mathrm{F}_{1}$ hybrid, and the mean of the $F_{1}$ hybrid population exceeds the mean of the two parent populations (Lamkey and Edwards, 1999). Panmictic high-parent heterosis is when the mean of the $F_{1}$ population exceeds the mean of the best parent. Panmictic heterosis has also been defined as heterotic deviation by Melchinger and Gumber (1998).

Optimal use of heterosis in crop breeding programs is facilitated by the classification and organization of germplasm into genetically divergent germplasm pools or heterotic groups (Melchinger and Gumber, 1998; Brummer, 1999; Melchinger, 1999). Melchinger and Gumber (1998, p. 30) define a heterotic group as "a group of related or unrelated genotypes from the same or different populations which display similar combining ability and heterotic response when crossed with genotypes from other genetically distinct germplasm groups." In crops such as maize, heterotic groups have long been recognized and exploited. In most forage or biomass crops, including switchgrass, heterotic groups have not been identified. Suggestions for identifying heterotic groups includes classifying germplasm based on genetic similarity or dissimilarity or by identifying adapted populations that have been isolated by time and space (Melchinger and Gumber, 1998; Melchinger, 1999). Representative genotypes from these populations can be intermated and their progeny can be evaluated in field trials with the parent genotypes or populations. Although genetic marker analyses can be useful in identifying potential heterotic groups, previous research indicates that heterotic response cannot be predicted by molecular or other markers but must be determined in field trials (Melchinger and Gumber, 1998; Melchinger, 1999). Kölliker et al. (2005), however, did find molecular markers useful for identifying diverse genotypes for inclusion in polycrosses for the production of synthetic varieties of perennial ryegrass (Lolium perenne L.)
Switchgrass is a polymorphic species with two distinct ecotypes, lowland and upland, and with two major ploidy levels, tetraploid $(2 n=4 x=36)$ and octaploid $(2 n=8 x=$ 72) (Vogel, 2004). Lowland types are found on flood plains and other areas subject to inundation, while upland types occur in upland areas that are not subject to flooding (Porter, 1966; Brunken and Estes, 1975). Lowland ecotypes are taller, more coarse, and generally more rust (Puccinia spp.) resistant, and they have a more bunch-type growth habit than upland ecotypes. Switchgrass is native to much of temperate North America east of the Rocky Mountains, and ecotypic variation also exists across the array of plant adaptation regions where it occurs naturally (Vogel, 2004; Vogel et al., 2005). It is a photoperiod-sensitive species, and the latitude of origin of germplasm is a primary determinant of its area of adaptation (Vogel, 2004; Casler et al., 2007a,b). Switchgrass has two cytoplasm types, L and $\mathrm{U}$, based on chloroplast DNA (cpDNA) polymorphisms that are associated with the lowland and upland ecotypes, respectively (Hultquist et al., 1996; Missaoui et al., 2006). The nuclear genetic distinctness of lowland and upland switchgrass cultivars was verified by Gunter et al. (1996) using cluster analysis of random amplified polymorphic DNA (RAPD) markers and by Missaoui et al. (2005) using restriction fragment length polymorphism (RFLP) markers. Ploidy level characterization studies aided by the use of flow cytometry indicate that most switchgrass cultivars are either tetraploid or octaploid (Hopkins et al., 1996; Lu et al., 1998). To date, all lowland plants that have been evaluated using chromosome counts of mitosis in root tips and flow cytometry analyses were tetraploids, while upland plants were tetraploids or octaploids. Tetraploid and octaploid plants were found occurring together in over half of the remnant prairies that were evaluated by Hultquist et al. (1997).

The first step in development of a hybrid cultivar system for a species such as switchgrass is the identification of heterotic groups. Brummer (1999) suggested that the most obvious potential heterotic groups of a species are either geographically separated populations or separate subspecies. Using the Brummer criteria, potential heterotic groups for switchgrass could be the tetraploid upland and lowland populations and western- and eastern-derived populations from the same latitudinal or plant hardiness zones. The objectives of this study were to evaluate potential heterotic groups of switchgrass for their potential when intermated to produce progeny that exhibit heterosis. Two types of hybrids were evaluated in this study. Population hybrids were used to determine if heterosis exists among plants from different populations and to determine of heterotic groups existed among the tested populations. Specific hybrids were used to determine if heterosis existed among individual plants from different genetic backgrounds. 


\section{MATERIALS AND METHODS}

Switchgrass cultivars and populations used in this study included four upland octaploid populations, one upland tetraploid population, and one lowland tetraploid population (Table 1). Upland (Summer) and lowland (Kanlow) tetraploid populations were used to test for ecotypic differentiation on the expression of heterosis. Two upland octaploid populations, 'Pathfinder' and Late Syn C3, from the western part of the original tall grass prairie region of the United States, and two populations, IL62 and 'Shawnee', which originate from Illinois collections, were used to evaluate potential heterosis among populations derived from spatially separated germplasm sources. Shawnee was developed by one cycle of breeding for high in vitro dry matter digestibility and high biomass yield from 'Cave-in-Rock', which originates from a collection made in southern Illinois in the eastern broadleaf forest ecoregion. Cave-in-Rock has been classified in some reports as a lowland ecotype (Alderson and Sharp, 1994), but with RFLP chloroplast markers it has the upland cytotype (Hultquist et al., 1996).

Both population and two-parent or specific hybrids were produced and evaluated. All hybrids were obtained using the mutual pollination method. The panicles of paired plants were enclosed together in paper pollination bags $(12$ by $41 \mathrm{~cm})$ before anthesis, using bamboo stakes to support the bags. To ensure pollination, only preanthesis panicles at the same physiological stage of development were bagged. After bagging, the bags were shaken every day to increase pollen dispersion. By using this method it was possible to obtain direct and reciprocal crosses at the same time. All crosses were made in the greenhouse from March to April in 1996. The procedure used to produce the hybrid populations was a form of chain crossing. As an example, in the Shawnee $\times$ Late Syn HYLD C3 crossing block, 20 Shawnee $(\mathrm{SH})$ plants were placed in a row on a greenhouse bench next to a row of 20 Late Syn HYLD C3 (L3) plants. Adjacent SH and L3 plants were intermated by mutual bagging of panicles. Likewise, adjacent SH plants were intermated to each other by mutual bagging of panicles to produce a $\mathrm{SH} \times \mathrm{SH}$ population, and adjacent $\mathrm{L} 3$ plants were also intermated with each other to produce a L3 $\times$ L3 population. For IL62, the plants that were intermated to L3 and to Pathfinder $(\mathrm{P})$ plants were intermated to produce IL62 $\times$ IL62(LC3) and IL62 $\times$ IL62(P) populations, respectively. Seed from the within-population crosses was used to verify that the sets of plants used to produce hybrids from the different cultivars and experimental strains did not produce progeny that differed in their mean performance from each other and the OBP.

The seed from the matings was used to produce both population and specific hybrids that were evaluated in separate field trials. Full-sib seed was harvested from the panicles of the maternal parent plant for each mating. For the specific hybrid trial, full-sib progeny from each maternal parent of a specific cross was a separate treatment. Only crosses $(n=9)$ for which there were at least 30 seedlings produced from each maternal parent were included in the specific hybrid trial. For the population hybrids, an equal number of seedlings from each individual direct and reciprocal cross not included in the specific hybrid trial was assembled and allocated to plots for which the population or population $\times$ population hybrid was the experimental treatment. Six parent populations, six betweenpopulation hybrids, and six within-population hybrids were

Table 1. Populations and cultivars used in switchgrass population and specific hybrid evaluations.

\begin{tabular}{|c|c|}
\hline Population/cultivar ${ }^{\dagger}$ & Description \\
\hline \multicolumn{2}{|l|}{ Parents } \\
\hline IL62 & Upland octaploid collected from prairie site in Illinois, 1989. \\
\hline Late Syn HYLD C3 (L3) & $\begin{array}{l}\text { Upland octaploid synthetic population produced by } 3 \text { cycles of recurrent breeding for high biomass yield by USDA grass } \\
\text { breeding project. Lincoln, NE. Based on western tallgrass prairie germplasm. }\end{array}$ \\
\hline 'Pathfinder’ (P) & $\begin{array}{l}\text { Upland octaploid synthetic cultivar derived from eastern Kansas and Nebraska germplasm collections by USDA grass } \\
\text { breeding project, Lincoln, NE. }\end{array}$ \\
\hline 'Shawnee' (SH) & $\begin{array}{l}\text { Upland octaploid developed by USDA grass breeding project by one breeding cycle for high-yield IVDMD in Cave-In- } \\
\text { Rock. Source population collected in southern Illinois. }\end{array}$ \\
\hline 'Summer’ (S) & Upland tetraploid. Developed from a collection from Nebraska City, NE, by South Dakota State University. \\
\hline ‘Kanlow’ (K) & Lowland octaploid developed by USDA SCS PMC, Manhattan, KS, from a collection in central Oklahoma. \\
\hline \multicolumn{2}{|l|}{ Progeny population } \\
\hline IL62 x L3 & Bulk population from 18 direct and reciprocal crosses between IL62 and Late Syn C3 plants. \\
\hline IL62 $\times \mathrm{P}$ & Bulk population from 18 direct and reciprocal crosses between IL62 and Pathfinder plants. \\
\hline $\mathrm{SH} \times \mathrm{P}$ & Bulk population from 4 direct and reciprocal crosses between Shawnee and Pathfinder plants. \\
\hline $\mathrm{SH} \times \mathrm{L3}$ & Bulk population from 6 direct and reciprocal crosses between Shawnee and Late Syn C3 plants. \\
\hline $\mathrm{K} \times \mathrm{S}$ & Bulk population from 12 Kanlow (female) by Summer (male) crosses. \\
\hline $\mathrm{S} \times \mathrm{K}$ & Bulk population from 12 Summer (female) by Kanlow (male) crosses. \\
\hline IL62 × IL62(L3) & Bulk population from 12 chain crosses involving IL62 plants used as parents for crossing with Late Syn C3 HYLD plants. \\
\hline IL62 × IL62(P) & Bulk population from 7 chain crosses involving IL62 plants used as parents for crossing with Pathfinder plants. \\
\hline L3 $\times$ L3 & Bulk population from 13 chain crosses of Late Syn C3 by Late Syn C3 plants. \\
\hline $\mathrm{P} \times \mathrm{P}$ & Bulk population from 7 chain crosses of Pathfinder by Pathfinder plants. \\
\hline $\mathrm{SH} \times \mathrm{SH}$ & Bulk population from 3 crosses of Shawnee by Shawnee plants. \\
\hline $\mathrm{K} \times \mathrm{K}$ & Bulk population from 6 chain crosses of Kanlow by Kanlow plants. \\
\hline
\end{tabular}

${ }^{\dagger}$ Specific hybrids are identified by population letter(s) followed by plant number within that population. Experimental populations are from the USDA-ARS grass breeding project, Lincoln, NE. The source of the cultivars is described by Vogel (2004) and Alderson and Sharp (1994). 
compared in the population hybrid trial. For the Summer $\times$ Kanlow crosses, sufficient seed was harvested separately from the maternal parents for comparisons of population hybrids by maternal parent. Seed from the OBPs was used to start seedlings in the greenhouse to compare the greenhouse-synthesized subpopulations with the plants produced from seed of the original populations.

The seed from hybrid progenies and OBPs was wet chilled at $5^{\circ} \mathrm{C}$ for $3 \mathrm{wk}$. On $13 \mathrm{Jan} .1997$ seeds were planted in conetainers $21 \mathrm{~cm}$ deep and $4 \mathrm{~cm}$ in diameter, filled with a mixture of soil, peat, and vermiculite (2:1:1 volume ratio) in a greenhouse with an 18-h photoperiod and a mean temperature of $28^{\circ} \mathrm{C}$. Seedlings were maintained in cone-tainers in the greenhouse until they were transplanted to the field. Water-soluble fertilizer (20-20-20) was applied twice to the seedlings in the greenhouse. Seedling vigor was measured in the greenhouse for the specific hybrid trial. In the greenhouse, a plot was two paired rows of five seedlings each. Forty-two days after planting, the 10 seedlings of a plot were harvested with a clipping height of $5 \mathrm{~cm}$, dried in a $50^{\circ} \mathrm{C}$ oven for $48 \mathrm{~h}$, and weighed. Sixweek seedling weights expressed on a per seedling dry weight basis were used as an estimate of seedling vigor. Seedlings were allowed to regrow and were then transplanted into field plots on 21 May 1997. A randomized complete block design with three replications was used in the greenhouse as well as in the field trial for the specific hybrids.

Field trials were located at the University of Nebraska Agricultural Research and Development Center near Mead, NE. For both trials, a field plot consisted of a single row of 10 plants spaced on 1.1-m centers. A border of one plant row was used around each replication to avoid any border effect. The population hybrid trial was a randomized incomplete block trial with six blocks or replicates. There were insufficient seedlings of some populations for inclusion in all replicates, hence the incomplete block design. Seedlings for the population hybrid trial were transplanted to a field on 20 May 1997. Hybrids were tested under noncompetitive conditions as spaced plants in both trials to allow the expression of the full potential of individual genotypes. Field plots were fertilized before planting with 112 $\mathrm{kg} \mathrm{N} \mathrm{ha}{ }^{-1}$ and $45 \mathrm{~kg} \mathrm{P}_{2} \mathrm{O}_{5} \mathrm{ha}^{-1}$ and sprayed after transplanting with a herbicide mixture of Dual [2-chloro-N-(2-ethyl-6methylphenyl)-N-(2-methoxy-1-methyl) acetamide], atrazine (6-chloro-N-ethyl-N-Isopropyl-1,3,5,-triazine-2,4.-diamine), and 2, 4-D-(2,4-dichlorophenoxyacetic acid) (1.1-2.2-1.1 kg a.i. ha ${ }^{-1}$, respectively).

First-year biomass yields for both trials were harvested just after a killing frost on 21 October, 1997. Plants were fully headed at the time of the frost. Plants were harvested with a plot flail harvester that left a stubble height of $10 \mathrm{~cm}$. Plots were sampled for dry matter determination at the time of harvest. The forage samples were dried at $50^{\circ} \mathrm{C}$ for $48 \mathrm{~h}$, and wet and dry weights were used to estimate dry matter content of all harvested biomass. All yields were converted to a dry matter basis. Not all seedlings survived transplanting. Plot yields were divided by surviving plants per plot to express yields on a per plant basis.

In 1998 and 1999, the plots were fertilized with $112 \mathrm{~kg}$ $\mathrm{N} \mathrm{ha}^{-1}$ in early spring and were treated with the same herbicides as in 1997 for weed control. The nurseries were rototilled bidirectionally each spring with a tractor rototiller that left untilled 0.46 - by $0.46-\mathrm{m}$ minisubplots occupied by individual plants, so all plants were evaluated on a uniform area basis with limited competition. In 1998 and 1999, plant height was measured before harvest. In 1998 and 1999, heading date was determined for the specific hybrids. Heading date for the population hybrids was recorded only in 1999. Heading date was the day of the year when the majority of the fertile tillers had panicles fully exerted from the boot, or maturity stage R3 (Moore et al., 1991). The population hybrid trial was harvested on 18-20 Aug. 1998 and on 26 Aug. 1999 using a forage flail harvester with a $10-\mathrm{cm}$ cutting height. The specific hybrid trial was harvested on 24 Aug. 1998 and on 27 Aug. 1999. All harvests occurred after the plants were fully headed. Harvested forage from each plot was sampled, weighed, and dried to determine dry matter percentage of the harvested forage. Dry matter percentages were used to convert harvest weights to biomass yields on a dry weight basis. Plot yields were divided by surviving plants per plot to express yields on a per plant basis.

Each parent cultivar was represented in the study by one or more populations. For example, Pathfinder was represented by plants produced from the original seed lot, as well as by plants produced from seed produced by chain-crossing Pathfinder plants in the greenhouse. Heterosis values were calculated and reported as mean differences (see below for equations), which permits the use of mean comparison statistics such as the LSD for comparing mean differences between hybrids and their parents.

\section{Midparent heterosis $=$ Hybrid mean - \\ $([$ Parent1 mean + Parent 2 mean $] / 2)$}

High-parent heterosis $=$ Hybrid mean - High-parent mean

All data were analyzed using the GLM procedure of version 6.12 of PC-SAS software (SAS Institute, 1996). Parent clones and populations were considered to be fixed effects. Seedling weight and first-year biomass yields were analyzed on a single-year basis. Mature plant (2- and 3-yr-old plants) biomass yield, plant height, and heading date were analyzed over years using a split plot in time analysis of variance (ANOVA) (data not shown). Since genotype $\times$ year effects were not significant for the main trait of interest (biomass yield), and since with perennials, means performance over years is of primary importance, plot means over years were used in ANOVA for mature plant biomass yield, plant height, and heading date. Protected LSD values were used to make mean comparisons and to test for significance of high-parent heterosis expressed as a mean difference or deviation. Midparent heterosis expressed as a deviation from the midparent mean was tested for statistical significance using planned linear mean comparisons (Snedecor and Cochran, 1989, p. 226-227).

\section{RESULTS}

In both the population hybrid and specific hybrid trials, there were significant differences among parent populations and hybrids for all traits that were evaluated, including seedling weight, first-year yields, two-year nonestablishment mean yields, plant height, and heading date (Tables 2 and 3). Except for seedling weight, which was determined 
Table 2. Mean squares from ANOVA for biomass yields, height, and heading date of switchgrass population hybrids and their parents. First-year yields were harvested in 1997, second- and third-year yields were harvested in 1998 and 1999.

\begin{tabular}{|c|c|c|c|c|c|c|}
\hline \multirow[b]{3}{*}{ Source } & \multirow{2}{*}{\multicolumn{2}{|c|}{ df }} & \multirow{3}{*}{$\begin{array}{l}\text { First-year } \\
\text { yields }\end{array}$} & \multicolumn{3}{|c|}{ Second and third year } \\
\hline & & & & \multirow{2}{*}{$\begin{array}{l}\text { Mean } \\
\text { yields }\end{array}$} & \multirow{2}{*}{$\begin{array}{l}\text { Mean } \\
\text { height }\end{array}$} & \multirow{2}{*}{$\begin{array}{c}\text { Mean heading } \\
\text { date }\end{array}$} \\
\hline & Yr 1 & $\operatorname{Yr} 2 \& 3$ & & & & \\
\hline & $n$ & $n$ & $\mathrm{~kg} \mathrm{plant}^{-1}$ & $\mathrm{~kg} \mathrm{plant}^{-1}$ & $\mathrm{~cm}$ & day of year \\
\hline Population & 17 & 17 & $0.084^{* *}$ & $0.449^{\star \star}$ & $1239^{\star *}$ & $19^{* *}$ \\
\hline Replicate & 3 & 5 & 0.003 & 0.047 & 253 & 6 \\
\hline Error & 37 & 52 & 0.005 & 0.029 & 308 & 7 \\
\hline
\end{tabular}

${ }^{* *}$ Significant at the 0.01 probability level.

in the greenhouse, replicate effects were small in the field trial. The ANOVA results indicate that the data from the field trials is statistically suitable for making comparisons between parents and hybrid progenies in both the population and specific hybrid trials.

\section{Population Hybrid Trial}

There were no significant differences between the OBPs and any of their derived subpopulations for the measured traits, indicating that subsets used in producing the population and specific hybrids were representative of their parent cultivar or strain (Table 4). Consequently, the OBP treatment mean in the trials was used in heterosis calculations as the parent mean for all hybrids. The Summer seedlings had very low first-year biomass yields in both trials, even though seedling vigor as indicated by seedling weight at 6 wk (Table 5) was similar to that of other cultivars and experimental populations in the trial. The reason for the low first-year yields is not known. By the second and third years, Summer biomass yields were in the same range as for the other upland cultivars. There were no significant differences between upland octaploid populations and their hybrids for first-year biomass yields, even though two of the cultivars, Shawnee and Pathfinder, had significantly different mean yields. This lack of differences among the upland octaploid parent and hybrid progeny populations is reflected in the numerically small midparent and high-parent heterosis values. Results were the same for second- and third-year mean biomass yields, plant height, and heading date. The upland tetraploid cultivar,

Table 3. Mean squares from ANOVA for individual seedling weight, and first- and second-year biomass yields of specific hybrids and their parent populations.

\begin{tabular}{|c|c|c|c|c|c|c|}
\hline \multirow[b]{2}{*}{ Source } & \multirow[b]{2}{*}{ df } & \multirow[b]{2}{*}{$\begin{array}{l}\text { Seedling } \\
\text { weight }\end{array}$} & \multirow[b]{2}{*}{$\begin{array}{c}\text { First-year } \\
\text { yields }\end{array}$} & \multicolumn{3}{|c|}{ Second and third year } \\
\hline & & & & $\begin{array}{l}\text { Mean } \\
\text { yields }\end{array}$ & $\begin{array}{c}\text { Mean } \\
\text { height }\end{array}$ & $\begin{array}{c}\text { Mean heading } \\
\text { date }\end{array}$ \\
\hline & $n$ & g seedling $^{-1}$ & $\mathrm{~kg} \mathrm{plant}^{-1}$ & $\mathrm{~kg} \mathrm{plant}^{-1}$ & $\mathrm{~cm}$ & day of year \\
\hline Hybrids and parents & 22 & $0.0106^{\star \star}$ & $0.043^{\star \star}$ & $0.287^{\star \star}$ & $830^{\star \star}$ & $66^{\star *}$ \\
\hline Replicate & 2 & $0.0218^{\star \star}$ & 0.007 & 0.015 & 9 & 1 \\
\hline Error & 42 & 0.0012 & 0.003 & 0.007 & 45 & 5 \\
\hline
\end{tabular}

${ }^{* *}$ Significant at the 0.01 probability level.
Summer, had significantly lower second- and thirdyear biomass yields than the upland octaploid cultivars, Pathfinder and Shawnee.

Kanlow and $\mathrm{K} \times \mathrm{S}$ and $\mathrm{S} \times \mathrm{K}$ population hybrids had significantly higher first-year biomass yields than all upland parent populations and hybrids except for Shawnee (Table 4). Shawnee had equivalent firstyear biomass yields to the $\mathrm{K} \times \mathrm{S}$ and $\mathrm{S} \times \mathrm{K}$ hybrids. The $\mathrm{K} \times \mathrm{S}$ and $\mathrm{S} \times \mathrm{K}$ hybrid populations had significantly lower first-year biomass yields than the Kanlow parent and had significantly greater yields than the Summer parent. Kanlow and the $\mathrm{K} \times \mathrm{S}$ hybrids had significantly higher second- and third-year mean biomass yields than any of the upland octaploid strains or strain hybrids. The $\mathrm{K} \times \mathrm{S}$ and $\mathrm{S} \times \mathrm{K}$ populations did not differ for nonestablishment year mean yields, indicating that there was no maternal effect on the populations for biomass yield. These hybrid populations had significantly greater postestablishment-year biomass yields than their Summer parent but had significantly lower biomass yields than their Kanlow parent. In this space-transplanted trial, there was no high-parent population heterosis for second- and third-year mean biomass yield. The midparent heterosis value expressed as a deviation from the parent cultivar means was significant for both the $\mathrm{K} \times \mathrm{S}$ and $\mathrm{S}$ $\times \mathrm{K}$ hybrid progeny populations, indicating the existence of midparent heterosis for second- and third-year mean biomass yield. The $\mathrm{K} \times \mathrm{S}$ and $\mathrm{S} \times \mathrm{K}$ hybrid populations were intermediate between their parents for plant height, but the differences were not significant. The $\mathrm{K} \times \mathrm{S}$ and $\mathrm{S} \times \mathrm{K}$ populations had significantly earlier heading dates than the Kanlow parent and were 1 or $2 \mathrm{~d}$ later in maturity than Summer.

\section{Specific Hybrid Trial}

Seedling vigor of a grass seed lot has both an environmental component, due to the production and nonproduction environment, and a genetic component. Genetic effects for grass seedling vigor traits should be made only for seed lots produced and processed in the same environments as per procedures similar to those followed by Smart et al. (2003). In this study, this limits comparisons to only the specific hybrids, so no estimates of heterosis can be made for seedling weight at $6 \mathrm{wk}$. For the Kanlow and Summer specific reciprocal hybrids, the specific hybrids for which Kanlow was the female parent had significantly greater seedling weight at $6 \mathrm{wk}$ than the for the same cross in which the female was a Summer plant (Table 5). There also was a significant maternal effect for two of the upland octaploid reciprocal crosses $(\mathrm{P}-6 \times$ IL62-5 and P-11 $\times$ IL62-14). This is the first report of a maternal effect on seedling vigor for 
Table 4. Switchgrass parent and hybrid populations mean biomass yields and plant height and associated midparent (MP) and high-parent (HP) heterosis expressed as deviations from the mid- and high-parent means.

\begin{tabular}{|c|c|c|c|c|c|c|c|c|c|c|}
\hline \multirow{3}{*}{ Population ${ }^{\dagger}$} & \multicolumn{3}{|c|}{ First-year biomass yield } & \multicolumn{6}{|c|}{ Second- and third-year biomass yield Second- and third-year plant height } & \multirow{3}{*}{$\begin{array}{l}\text { Heading } \\
\text { date }\end{array}$} \\
\hline & \multirow[b]{2}{*}{ Yield } & \multicolumn{2}{|c|}{ Heterosis } & \multirow[b]{2}{*}{ Yield } & \multicolumn{2}{|c|}{ Heterosis } & \multirow[b]{2}{*}{ Height } & \multicolumn{2}{|c|}{ Heterosis } & \\
\hline & & MP & HP & & MP & HP & & MP & HP & \\
\hline & $\mathrm{kg} \mathrm{plant}^{-1}$ & $\mathrm{~kg} \mathrm{plant}^{-1}$ & $\mathrm{~kg} \mathrm{plant}^{-1}$ & $\mathrm{~kg} \mathrm{plant}^{-1}$ & $\mathrm{~kg} \mathrm{plant}^{-1}$ & $\mathrm{~kg} \mathrm{plant}^{-1}$ & $\mathrm{~cm}$ & $\mathrm{~cm}$ & $\mathrm{~cm}$ & day of year \\
\hline IL62 & 0.19 & & & 0.88 & & & 181 & & & 230 \\
\hline IL62 × IL62(L3) & 0.13 & & & 0.80 & & & 181 & & & 228 \\
\hline IL62 × IL62(P) & 0.13 & & & 0.91 & & & 181 & & & 230 \\
\hline L3 & 0.16 & & & 0.83 & & & 187 & & & 227 \\
\hline $\mathrm{L} 3 \times \mathrm{L} 3$ & 0.15 & & & 0.76 & & & 183 & & & 228 \\
\hline P & 0.10 & & & 0.91 & & & 183 & & & 228 \\
\hline$P \times P$ & 0.11 & & & 0.74 & & & 188 & & & 229 \\
\hline IL62 $\times$ L3 & 0.14 & -0.04 & -0.05 & 0.96 & 0.11 & 0.08 & 183 & -1 & -4 & 229 \\
\hline IL62 × P & 0.13 & -0.02 & -0.06 & 0.80 & -0.10 & -0.11 & 180 & -2 & -3 & 227 \\
\hline $\mathrm{SH}$ & 0.30 & & & 1.00 & & & 188 & & & 228 \\
\hline $\mathrm{SH} \times \mathrm{SH}$ & 0.30 & & & 0.99 & & & 196 & & & 230 \\
\hline $\mathrm{SH} \times \mathrm{L} 3$ & 0.21 & -0.02 & -0.09 & 1.02 & 0.11 & 0.02 & 190 & 3 & 2 & 226 \\
\hline $\mathrm{SH} \times \mathrm{P}$ & 0.19 & -0.01 & -0.11 & 1.02 & 0.07 & 0.02 & 196 & 10 & 8 & 230 \\
\hline K & 0.68 & & & 1.83 & & & 218 & & & 237 \\
\hline $\mathrm{K} \times \mathrm{K}$ & 0.59 & & & 1.78 & & & 209 & & & 234 \\
\hline S & 0.04 & & & 0.72 & & & 189 & & & 228 \\
\hline $\mathrm{K} \times \mathrm{S}$ & 0.28 & -0.08 & -0.04 & 1.56 & $0.29^{*}$ & -0.27 & 201 & -3 & -17 & 229 \\
\hline$S \times K$ & 0.35 & 0.01 & -0.33 & 1.47 & $0.20^{*}$ & -0.36 & 203 & -0.5 & -15 & 230 \\
\hline LSD 0.05 & 0.11 & & 0.11 & 0.17 & & 0.17 & 18 & & 18 & 4 \\
\hline
\end{tabular}

*The $t$ test for the planned linear comparison between the hybrid and midparent mean was significant at the 0.05 probability level.

†P, 'Pathfinder'; K, 'Kanlow'; SH, 'Shawnee'; S, 'Summer'; L3, Late Syn HYLD C3; see Table 1 for full description of population and population hybrid.

switchgrass, and it may be an important consideration in potential hybrid seed production systems.

The biomass yield results for the specific hybrids were similar to those for the population hybrids. No positive heterosis was exhibited for establishment year biomass yields. Three out of the four $\mathrm{K} \times \mathrm{S}$ specific hybrids exhibited significant positive midparent heterosis for second- and third-year mean biomass yields. One specific $\mathrm{S} \times \mathrm{K}$ hybrid had significantly lower mean second- and third-year biomass yields than the midparent value but did not differ in yield from Summer. None of the upland octaploid specific hybrids exhibited any positive mid- or high-parent heterosis for biomass yield. As expected, there were significant differences among the specific hybrids for establishment and nonestablishment-years biomass yields. The Kanlow and Summer hybrids were intermediate between their parents for both plant height and heading date. They all were significantly shorter in plant height than Kanlow.

\section{DISCUSSION}

The results of both the population and specific hybrid trials indicate that lowland tetraploids represented by the cultivar Kanlow and the upland tetraploids represented by the cultivar Summer represent two distinct heterotic groups. Significant midparent heterosis for nonestablishmentyear biomass yield existed among their progeny for both population and specific hybrids. Both of these cultivars are synthetic varieties and are genetically heterogenous. Hence there was variation among their specific hybrids for all traits evaluated. In contrast, the octaploid-tetraploid cultivars and experiment populations used in this study appear to be from the same heterotic group even though they were derived from spatially separated populations. These results are consistent with the nuclear genetic distinctness of lowland and upland switchgrass cultivars reported previously by Gunter et al. (1996) and Missaoui et al.(2005) using RAPD and RFLP markers, respectively. In a recent report, Casler et al. (2007a) reported that switchgrass germplasm from areas equivalent to plant adaptation regions (Vogel et al., 2005) are essentially large germplasm pools based on molecular marker analysis. The lack of heterosis among progeny of both populations and specific hybrids of the upland octaploid cultivars and experimental strains used in this study indicates that they are part of the same or very closely associated germplasm pool or heterotic group, which supports the conclusions of Casler et al. (2007a).

Switchgrass is a cross-pollinated species, and crosspollination is enforced by a gametophytic self-compatibility system that is similar to the $\mathrm{S}-\mathrm{Z}$ incompatibility system found in other Poaceae (Martinez-Reyna and Vogel, 2002). Pollen is dispersed by wind. Percentages of selfcompatibility as measured by seed set from bagged panicles 
Table 5. Switchgrass parent population and specific hybrids mean seedling weight, biomass yields, and plant height and associated midparent (MP) and-high parent (HP) heterosis expressed as deviations from the mean of mid- and highparent populations.

\begin{tabular}{|c|c|c|c|c|c|c|c|c|c|c|c|}
\hline \multirow{3}{*}{ Population $^{\dagger}$} & \multirow{3}{*}{$\begin{array}{l}\text { Seedling } \\
\text { weight }\end{array}$} & \multicolumn{3}{|c|}{ First year biomass yield } & \multirow{2}{*}{\multicolumn{3}{|c|}{$\frac{\text { Second and third year biomass yield }}{\text { Heterosis }}$}} & \multirow{2}{*}{\multicolumn{3}{|c|}{$\frac{\text { Second and third year height }}{\text { Heterosis }}$}} & \multirow{3}{*}{$\begin{array}{l}\text { Head } \\
\text { date }\end{array}$} \\
\hline & & \multirow[b]{2}{*}{ Mean } & \multicolumn{2}{|c|}{ Heterosis } & & & & & & & \\
\hline & & & MP & HP & Mean & MP & HP & Mean & MP & HP & \\
\hline & g plant ${ }^{-1}$ & $\mathrm{~kg} \mathrm{plant}^{-1}$ & $\mathrm{~kg} \mathrm{plant}^{-1}$ & $\mathrm{~kg} \mathrm{plant}^{-1}$ & $\mathrm{~kg}$ plant $^{-1}$ & $\mathrm{~kg} \mathrm{plant}^{-1}$ & $\mathrm{~kg}$ plant $^{-1}$ & $\mathrm{~cm}$ & $\mathrm{~cm}$ & $\mathrm{~cm}$ & day of year \\
\hline K & 0.375 & 0.68 & & & 1.63 & & & 179 & & & 237 \\
\hline S & 0.375 & 0.10 & & & 0.71 & & & 132 & & & 219 \\
\hline $\mathrm{K}-9 \times \mathrm{S}-9$ & 0.443 & 0.29 & -0.10 & -0.41 & 1.52 & $0.35^{*}$ & -0.11 & 139 & -17 & -40 & 229 \\
\hline $\mathrm{S}-9 \times \mathrm{K}-9$ & 0.302 & 0.27 & -0.12 & -0.25 & 1.35 & $0.18^{*}$ & -0.28 & 138 & -18 & -41 & 224 \\
\hline $\mathrm{K}-6 \times \mathrm{S}-30$ & 0.506 & 0.43 & 0.04 & -0.56 & 1.45 & $0.28^{*}$ & -0.18 & 143 & -13 & -36 & 229 \\
\hline $\mathrm{S}-30 \times \mathrm{K}-6$ & 0.327 & 0.12 & -0.27 & -0.44 & 0.80 & -0.37 & -0.83 & 132 & -24 & -47 & 223 \\
\hline IL62 & 0.410 & 0.24 & & & 0.88 & & & 107 & & & 225 \\
\hline$P$ & 0.296 & 0.17 & & & 0.63 & & & 113 & & & 221 \\
\hline L3 & 0.386 & 0.28 & & & 0.76 & & & 112 & & & 223 \\
\hline IL62-1 × P-1 & 0.480 & 0.21 & 0.01 & -0.03 & 0.81 & 0.06 & -0.07 & 101 & -9 & -12 & 222 \\
\hline P-1 $\times$ IL62-1 & 0.446 & 0.19 & -0.02 & -0.05 & 0.82 & 0.06 & -0.06 & 104 & -6 & -9 & 223 \\
\hline IL62-2 × P-2 & 0.403 & 0.18 & -0.02 & -0.06 & 0.82 & 0.06 & -0.06 & 123 & 13 & 10 & 213 \\
\hline P-2 × IL62-2 & 0.406 & 0.18 & -0.02 & -0.06 & 0.70 & -0.06 & -0.18 & 127 & 17 & 14 & 215 \\
\hline IL62-3 x P-3 & 0.386 & 0.24 & 0.04 & 0 & 0.81 & 0.05 & -0.07 & 125 & 15 & 12 & 222 \\
\hline P-3 x IL62-3 & 0.413 & 0.26 & 0.06 & 0.02 & 0.86 & 0.10 & -0.02 & 130 & 20 & 17 & 224 \\
\hline IL62-5 × P-6 & 0.310 & 0.19 & -0.01 & -0.05 & 0.76 & 0.00 & -0.12 & 114 & 4 & 1 & 220 \\
\hline P-6 $\times$ IL62-5 & 0.376 & 0.14 & -0.06 & -0.1 & 0.51 & -0.25 & -0.37 & 121 & 11 & 8 & 223 \\
\hline IL62-14 × P-11 & 0.370 & 0.24 & 0.04 & 0 & 0.76 & 0.00 & -0.12 & 127 & 17 & 14 & 223 \\
\hline $\mathrm{P}-11 \times \| 62-14$ & 0.483 & 0.24 & 0.04 & 0 & 0.78 & 0.02 & -0.10 & 126 & 16 & 13 & 221 \\
\hline IL62-24 × P-15 & 0.466 & 0.19 & -0.02 & -0.05 & 0.83 & 0.07 & -0.05 & 116 & 6 & 3 & 222 \\
\hline P-15 x IL62-24 & 0.496 & 0.22 & 0.02 & -0.02 & 0.67 & -0.09 & -0.21 & 118 & 8 & 5 & 221 \\
\hline IL62-32 x L3-8 & 0.366 & 0.15 & -0.11 & -0.13 & 0.47 & -0.35 & -0.41 & 109 & -1 & -3 & 222 \\
\hline L3-8 x IL62-32 & 0.380 & 0.12 & -0.14 & -0.16 & 0.53 & -0.29 & -0.35 & 108 & -2 & -4 & 223 \\
\hline $\mathrm{LSD}_{0.05}$ & 0.056 & 0.09 & & 0.09 & 0.10 & & 0.10 & 8 & & 8 & 3 \\
\hline
\end{tabular}

${ }^{*}$ The $t$ test for the planned linear comparison between the hybrid and midparent mean was significant at the 0.05 probability level.

tP, 'Pathfinder'; K, 'Kanlow'; SH, 'Shawnee'; S, 'Summer'; L3, Late Syn HYLD C3.

is typically less than 1\% (Talbert et al., 1983; MartinezReyna and Vogel, 2002). A nonfertilization incompatibility system also exists that inhibits intermatings among octaploid and tetraploid plants (Martinez-Reyna and Vogel, 2002). The ecotypes or cytotypes of switchgrass are cross-fertile when plants with the same ploidy level are intermated (Martinez-Reyna et al., 2001). The existence of gametophytic self-incompatibility in switchgrass may make it feasible to develop switchgrass hybrid cultivars using the method illustrated in Figure 1. If two plants are identified that produce superior $\mathrm{F}_{1}$ hybrids, then the two plants can be vegetatively increased and transplanted into seed production fields (Burton, 1989; Vogel, 2000; Vogel and Burson, 2004). All the seed harvested from the fields would be $\mathrm{F}_{1}$ hybrid seed, assuming that proper isolation of the seed field was maintained. Two bahiagrass (Paspalum notatum Flüggé) cultivars were developed using a similar method but were not successful because of the labor and cost of establishing seed production fields (Burton, 1989). Improvements in tissue culture for clonally propagating plants, such as a node propagation method developed in the laboratory of Dr. Bob Conger (Alexandrova et al., 1996), and in mechanical transplanters should make hybrids based on self-incompatibility commercially feasible. These seed fields could be maintained for many years for perennial grasses. Foster (1971a,b) described and tested a similar scheme in which bulk population hybrids (50\% hybrids) would be produced by interplanting different populations but did not identify heterotic groups.

Results of this study indicate that for switchgrass, population hybrids can be used to identify heterotic groups or populations of plants that exhibit heterosis when hybridized. Within identified heterotic groups, specific genotypes would need to be identified for optimum expression of heterosis by test crosses with genotypes from a different heterotic group(s). Based on these results, initial steps to follow in developing a switchgrass hybrid breeding program would be to classify available germplasm by ploidy level using a rapid method such as flow cytometry, by cytotype using chloroplast DNA markers, and by plant adaptation region 
of origin using collection information. Because of the large number of potential hybrid combinations, molecular markers may be useful in further classifying plant material into germplasm pools. Population hybrids can then be made from divergent germplasm pools to classify switchgrass populations into heterotic groups by the performance of their hybrids in field trials. Superior genotypes can then be selected from within the populations for use in producing and evaluating specific $\mathrm{F}_{1}$ hybrids in field trials. Best genotypes can then be increased vegetatively for the establishment of transplanted seed production fields

Since many switchgrass populations have undergone limited numbers of breeding cycles, within-population breeding programs to improve the base populations should result in genetic improvements of the both the base populations and hybrids developed from genotypes selected from these populations. Reciprocal, recurrent selection for combining ability also could be used in later generations. As suggested previously by Brummer (1999), breeders should avoid combining germplasm from different potential heterotic groups to form synthetic breeding populations if they expect to utilize heterosis in future generations.

It will be necessary for genotypes to flower during the same period to be used in a hybrid seed production system similar to that described in Figure 1, and they should be adapted to the intended geographical area of use. Kanlow is a very high yielding lowland cultivar that originated in the southern plains of the United States. However, it is highly susceptible to winter killing in the northern half of the United States, and its peak flowering is about 2 to 3 wk later than that of Summer, which is adapted to midlatitudes of the United States and has good winter hardiness. Although both population and specific hybrids from these two parents exhibited midparent heterosis, additional breeding work will be needed to synchronize flowering in these cultivars before they can be successfully used as germplasm sources for parents of hybrid cultivars. Fortunately, there is significant variation for heading or flowering date in both cultivars and winter survival in Kanlow.

Switchgrass is grown in solid stands or swards in pastures or hay fields. The applicability of spaced-planted results to swards for switchgrass needs to be addressed. Switchgrass
Production of F1 Hybrid Grass Cultivars

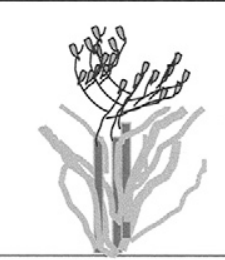

$\mathrm{F}_{1} \quad \mathrm{~B}$

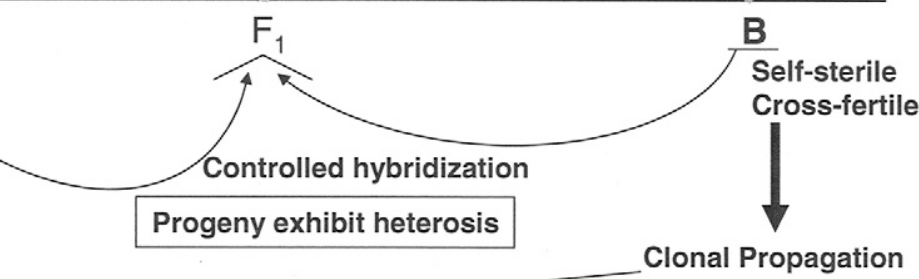

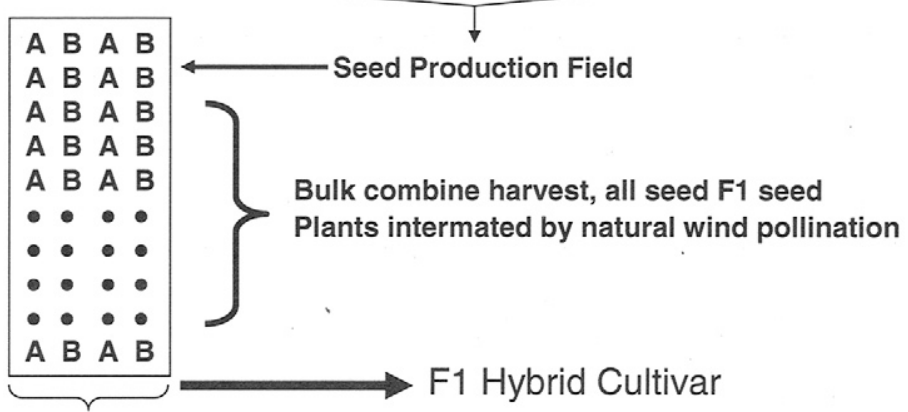

\section{F1 Hybrid Cultivar}

Figure 1. A schematic of a system for produce $F_{1}$ hybrid seed of a cross-pollinated perennial grass utilizing self-incompatibility as the mechanism to control pollination. Genotypes from different heterotic groups would be intermated using controlled crosses to produce hybrid progeny for heterosis testing. Two genotypes producing progeny with superior heterosis would be increased vegetatively or asexually and transplanted into isolated seed production fields. All seed harvested from the field would be $F_{1}$ hybrid seed. (Figure artwork courtesy of Gautam Sarath, USDA-ARS, Lincoln, NE.)

forage or biomass yields have been improved by 20 to $30 \%$ from existing parent germplasm by traditional grass-breeding techniques, which included space-transplanted selection nurseries (McLaughlin and Kszos, 2005). While no direct comparison or correlation studies have been made between strain ranks in space-planted versus sward trials, comparisons of yields of switchgrass strains that were included as checks in a germplasm evaluation trials (Hopkins et al., 1995a) with their relative rank in an adjacent sward yield tests at three different Midwest locations (Hopkins et al., 1995b) indicate that space-planted biomass yields of switchgrass strains are predictive of their yield in swards. However, the extent of heterosis in switchgrass for biomass yield in sward conditions still needs to be determined. In addition, the effect of advance in generation on heterosis for switchgrass also needs to be determined.

\section{References}

Alderson, J., and W.C. Sharp. 1994. Grass varieties in the United States. Agricultural Handbook No. 170. USDA, Soil Conservation Service, Washington, DC.

Alexandrova, K.S., P.D. Denchev, and B.V. Conger. 1996. Micropropagation of switchgrass by node culture. Crop Sci. 36:1709-1711. 
Brummer, E.C. 1999. Capturing heterosis in forage crop cultivar development. Crop Sci. 39:943-954.

Brunken, J.N., and J.R. Estes. 1975. Cytological and morphological variation in Panicum virgatum L. Southwest. Nat. 19:379-385.

Burton, G.W. 1989. Progress and benefits to humanity from breeding warm-season forage grasses. p. 21-29. In D.A. Sleper, K.H. Asay, and J.F. Pedersen (ed.) Contributions from breeding forage and turf grasses. CSSA Spec. Publ. 15. CSSA, Madison, WI.

Casler, M.D., C.A. Stendal, L. Kapich, and K.P. Vogel. 2007a. Genetic diversity, plant adaptation regions, and restoration gene pools for switchgrass. Crop Sci. 47:2261-2273.

Casler, M.D., K.P. Vogel, C.M. Taliaferro, N.J. Ehlke, J.D. Berdahl, E.C. Brummer, R.I. Kallenbach, C.P. West, and R.B. Mitchell. 2007b. Latitudinal and longitudinal adaptation of switchgrass populations. Crop Sci. 47:2249-2260.

Foster, C.A. 1971a. Interpopulation and intervarietal hybridization in Lolium perenne breeding: Heterosis under non-competitive conditions. J. Agric. Sci. 76:107-130.

Foster, C.A. 1971b. Interpopulation and intervarietal $F_{1}$ hybrids in Lolium perenne: Heterosis under simulated sward conditions. J. Agric. Sci. 76:401-409.

Gunter, L.E., G.A. Tuskan, and S.D. Wullschleger. 1996. Diversity among populations of switchgrass based on RAPD markers. Crop Sci. 36:1017-1022.

Hopkins, A.A., C.M. Taliaferro, C.D. Murphy, D. Christopher, and D. Christian. 1996. Chromosome number and nuclear DNA content of several switchgrass populations. Crop Sci. 36:1192-1195.

Hopkins, A.A., K.P. Vogel, K.J. Moore, K.D. Johnson, and I.T. Carlson. 1995a. Genetic variability and genotype $\times$ environment interactions among switchgrass accessions from the midwestern USA. Crop Sci. 35:565-571.

Hopkins, A.A., K.P. Vogel, K.J. Moore, K.D. Johnson, and I.T. Carlson. 1995b. Genotype effects and genotype by environment interactions for traits of elite switchgrass populations. Crop Sci. 35:125-132.

Hultquist, S.J., K.P. Vogel, D.J. Lee, K. Arumuganathan, and S. Kaeppler. 1996. Chloroplast DNA and nuclear DNA content variations among cultivars of switchgrass, Panicum virgatum L. Crop Sci. 36:1049-1052.

Hultquist, S.J., K.P. Vogel, D.E. Lee, K. Arumuganathan, and S. Kaeppler. 1997. DNA content and chloroplast DNA polymorphisms among accessions of switchgrass from remnant midwestern prairies. Crop Sci. 37:595-598.

Kölliker, R., B. Boller, and F. Widmer. 2005. Marker assisted polycross breeding to increase diversity and yield in perennial ryegrass (Lolium perenne L.). Euphytica 146:55-65.

Lamkey, K.R., and J.W. Edwards. 1999. Quantitive genetics of heterosis. p. 31-48. In J.G. Coors and S. Pandey (ed.) Genetics and exploitation of heterosis in crops. ASA and CSSA, Madison, WI.

Lu, K., S.M. Kaeppler, K.P. Vogel, K. Arumuganathan, and D.J. Lee. 1998. Nuclear DNA content and chromosome numbers in switchgrass. Great Plains Res. 8:269-280.

Martinez-Reyna, J.M., and K.P. Vogel. 2002. Incompatibility systems in switchgrass. Crop Sci. 42:1800-1805.

Martinez-Reyna, J.M., K.P. Vogel, C. Caha, and D.J. Lee. 2001. Meiotic stability, chloroplast DNA polymorphisms, and morphological traits of upland $\times$ lowland switchgrass reciprocal hybrids. Crop Sci. 41:1579-1583.

McLaughlin, S.B., and L.A. Kszos. 2005. Development of switchgrass (Panicum virgatum) as a bioenergy feedstock in the United States. Biomass Bioenergy 28:515-535.

Melchinger, A.E. 1999. Genetic diversity and heterosis. p. 99-118. In J.G. Coors and S. Pandey (ed.) Genetics and the exploitation of heterosis in crops. ASA and CSSA, Madison, WI.

Melchinger, A.E., and R.K. Gumber. 1998. Overview of heterosis and heterotic groups in agronomic crops. p. 29-44. In K.R. Lambey and J.E. Staub (ed.) Concepts and breeding of heterosis in crop plants. CSSA Spec. Publ. 25. CSSA, Madison, WI.

Missaoui, A.M., A.H. Patterson, and J.H. Bouton. 2005. Investigation of genomic organization in switchgrass (Panicum virgatum L.) using DNA markers. Theor. Appl. Genet. 110:1372-1383.

Missaoui, A.M., A.H. Paterson, and J.H. Bouton. 2006. Molecular markers for the classification of switchgrass (Panicum virgatum L.) germplasm and to assess genetic diversity in three synthetic switchgrass populations. Genet. Resour. Crop Evol. 53:1291-1302.

Moore, K.J., L.E. Moser, K.P. Vogel, S.S. Waller, B.E. Johnson, and J.F. Pedersen. 1991. Describing and quantifying growth stages of perennial forage grasses. Agron. J. 83:1073-1077.

Porter, C.L. 1966. An analysis of variation between upland and lowland switchgrass Panicum virgatum L. in central Oklahoma. Ecology 47:980-992.

SAS Institute. 1996. Version 6.17 PC SAS. SAS Inst., Cary, NC.

Smart, A.J., K.P. Vogel, L.E. Moser, and W.W. Stroup. 2003. Divergent selection for seedling tiller number in big bluestem and switchgrass. Crop Sci. 43:1427-1433.

Snedecor, G.W., and W.G. Cochran. 1989. Statistical methods. Iowa State Univ. Press, Ames.

Talbert, L.E., D.H. Timothy, J.C. Burns, and J.O. Rawlings. 1983. Estimates of genetic parameters in switchgrass. Crop Sci. 23:725-728.

Vogel, K.P. 2000. Improving warm-season grasses using selection, breeding, and biotechnology. p. 83-106. In K.J. Moore and B. Anderson (ed.) Native warm-season grasses: Research trends and issues. CSSA Spec. Publ. 30. CSSA and ASA, Madison, WI.

Vogel, K.P. 2004. Switchgrass. p. 561-588. In L.E. Moser, L. Sollenberger, and B. Burson (ed.) Warm-season $\left(\mathrm{C}_{4}\right)$ grasses. ASA, CSSA, and SSSA, Madison, WI.

Vogel, K.P., and B. Burson. 2004. Breeding and genetics. p. 51-96. In L.E. Moser, L. Sollenberger, and B. Burson (ed.) Warmseason $\left(\mathrm{C}_{4}\right)$ grasses. ASA, CSSA, and SSSA, Madison, WI.

Vogel, K.P., and J.F. Pedersen. 1993. Breeding systems for crosspollinated perennial grasses. Plant Breed. Rev. 11:251-274.

Vogel, K.P., M.R. Schmer, and R.B. Mitchell. 2005. Plant adaptation regions: Ecological and climatic classification of plant materials. Rangeland Ecol. Manage. 58:315-319. 